\title{
Implementing Comic in Learning English Vocabulary in Pharmacy Students of STIKes Buleleng
}

\author{
Kadek Devy Marleni , Putu Windi Ridayanti, Ni Nyoman Ari Ratnadi \\ Sekolah Tinggi Ilmu Kesehatan Buleleng \\ Email: $\underline{\text { devy26marleni@gmail.com, windiridayanti@gmail.com, ariratnadi@gmail.com }}$
}

\begin{abstract}
The success of the teaching-learning process is not only supported by the students but also by the teacher as central learning. In this case, students and teachers have an equally important role. The students will be enthusiastic in learning when they have good teachers in transfer information, material, and knowledge. Teaching English as a foreign language to adult students is not essay job to do. It needs kinds of strategies in teaching and method to transform knowledge into them. It is because English is difficult and not an essay to be learned for them. English language as a foreign language has so many challenges to be faced when learned it. Many factors showed that English is difficult to be learned by students at a higher level such as they are lack vocabulary, confusing to express their ideas, lazy to practice English, bored in teaching strategy, or media that lecture used. In this situation, the lecture should choose appropriate media, strategy, or method when teaching. And one of the media can be used is comic. Comics are a series of pictures that contain images and balloons to write a story. This research showed that learning by implementing comics was so significant to improve students' willingness in learning vocabulary. It prof by the increasing mark of students in English objects, the present list was always full and the atmosphere of the classroom is so lively. The class was always happy, enthusiastic, and comfortable to follow the lesson.
\end{abstract}

Keywords: vocabulary, comic, learning

\section{Introduction}

English as a foreign language should be taught in every curriculum in Indonesia's school started in elementary school until grade students in university or high school. It is because English has a role in the international era as world communication language and English is so important to support continuities of opportunity to find a job in another country. But on the contrary, English is difficult to be learned by students because English is different from the Indonesia language from the system of structure, pronunciation, spelling, and vocabulary. In this case not only students at lower-level face this situation the higher students also have the same problems in learning English.

Teaching English as a foreign language to adult students is not essay job to do. It needs kinds of strategies in teaching and method to transform knowledge into them. It is because English is difficult and not an essay to be learned for them. English language as a foreign language has so many challenges to be faced when learned it. Many factors showed that English is difficult to be learned by students at a higher level such as they are lack vocabulary, confusing to express their ideas, lazy to practice English, bored in teaching strategy or media I 
learning English and so many other reasons. As teacher knows many factors influence the result of the language teaching, such as reading, speaking, listening, and writing. Students cannot express an idea or opinion without knowing English Vocabulary. Mastering vocabulary is needed to understand paragraphs, articles, conversations, listening, and also speaking. It is because vocabulary has an important role in learning English. As much as students know the vocabulary in their mind it will be better to help them in mastery English and it will be basic to learn English well.

The success of the teachinglearning process is not only supported by the students but also by the teacher as central learning. In this case, students and teachers have an equally important role. The students will be enthusiastic in learning when they have a good teacher in transfer information, material, and knowledge. The students will happily learn English when the teacher has a variety of methods, strategies, and media in the learning process so that the class is not monotonous. The teacher should be realized that learning English is not an essay for them so she/he would help them to understand and manage the classroom in interesting ways.

According to the facts above, the students in STIKes Buleleng also faced problems when they learn English. Most of them still lack mastery vocabulary as basic in learning English. They are so difficult to show their ideas, feelings, opinions so that most of them only keep silent and hide in other students' back when learning English. Vocabulary as basic was taught in elementary school until junior high school although indirectly in material learning but in fact they still have weakness in vocabulary. Most of them said that English is so difficult to be learned because the structure is so different from Indonesia. They also said that pronunciation is so different from the spelling and it makes them confuse and lazy to learn it. Lecture knows that the lack of vocabulary is one factor they said like that. Vocabulary refers to a list or a set of words individual speakers of language might use (Hatch and Browns, 1995:1). Hammer (1991: 62) explains that teaching vocabulary does not only teach the new meaning of words but also teaches how to spell and how to pronounce the words. Teaching vocabulary in early English learning is very important. Students will find difficulties in learning English if they lack vocabulary. Teaching vocabulary is not an essay because it needs serious attention from students and lecturers.

In the real teaching-learning process, teaching vocabulary is not as easy as a teacher imagines. There are some problems that also occurred during the process of teaching and learning. The problems were: (1) Students did not pay attention to the lesson; (2) When the teacher gave explanations, students talked to each other, it made the class noisy; (3) Students in the class were passive. Based on the problem in the classroom 
situation, it can be said that the students had low motivation in learning English. Based on the observation in the classroom, those problems were mainly caused by three things: (1) the teacher has not utilized teaching media for the teaching and learning process. (2) the teacher did not use a variety of effective teaching techniques to teach the students. (3) the students do not have enough motivation to learn English. They assumed that English is quite difficult for them. In this case, the teacher should have the good and appropriate technology and media to teach vocabulary to the students so that the students are interested to learn and have attention to the lesson. As the teacher knows teaching technic and media is an important thing in teaching English because it helps students to understand the materials. It becomes a great challenging act for a lecture to teach vocabulary, what kinds of method, or how many vocabularies that should be taught.

Vocabulary is so important to be taught because by mastering vocabulary students will be able in producing sentences either in spoken or written ones. To make teaching vocabulary more interesting, good media is needed. Media in teaching is a tool or the physical things used by a lecturer to facilitate the instruction. As much as the media used in transferring material it will be good for a student in accepting the lesson. In this case, the lecture should have good choices in use media or strategy when they teach vocabulary. It is because students' characteristics are different between each other, the willingness of students also influence their comfort in learning, difficulties of media, and strategy bee weaknesses of lecturers in teaching vocabulary. So in this case lecture should be wise in choosing media and strategy in teaching.

Related to problems above lectures should behave method, strategy, and also learning media to help them in learning. And one way to help them in the teaching-learning process is by using comic as media in learning English. The comic is one of many media to teach vocabulary. Using a comic in teaching vocabulary can be very interesting and pleasant for students. They will feel something new and different from what they usually get in the class. They also will be active as participants and have more chances to express their minds, emotion, feeling, and attitude. The comic is an artistic medium where images with text or other forms of information in order to express the ideas. Comics are a series of pictures that contain images and balloons to write the story. Comics are fun to be introduced to the students. It is because by reading a comic, the students will not be bored to read because a comic contains pictures and images. The colorful comics will make the student enjoy reading it. Comics can also motivate the students to write because by seeing pictures or images in the comics, the students' ideas will occur and give a lot of inspiration for them. Based on the explanation above comic is helpful in increase vocabulary students in English. By 
seeing pictures in comic students will be an essay to remember vocabulary that they learned because it helps by pictures given.

The beneficial of comic
according
(www.genayang.com/comicsedu/stre nght,html) can be described as follow: 1) Motivation. Through comic lecturers can motivated students in learning vocabulary. Most students enjoy reading comics not only offline but also online. It will motivate students to enrich vocabulary itself and they will not realize that they learn English directly. The use of colors, the name of parts of medicine, or illness and sickness can be studied and understand fast with the use of cartoon comics. 2) Visual. Pictures in comics will help students with memories words about materials given it because the picture given is enjoyable, colorful, and eye-catching. 3) Intermediary. Comics can serve as an intermediate step too difficult disciplines and concepts. Many languages are educators have used comic in this manner with tremendous success.

Study English vocabulary is not an essay, the students should have a lot of knowledge to show their meaning in writing, speaking, and also listening and reading. When they speak to foreign they are able to choose the right words and good pronoun with them. When they read English written they understand the meaning of the written and when they listening to someone pronoun they understand it well. So the lecturer gives comic as media in learning. By using comic wishes students essay to learn and get the main materials given. Comic helps and guides students in learning because comic is interesting media, comic content of color and pictures, comic enjoy to learn, and comic give interesting to students so that they are not bored and stress when learning English.

\section{Discussion}

The object of this research is pharmacy students of STIKes Buleleng. It is chosen because most of them are lack of vocabulary and also difficult to understand English in general. This research uses a descriptive method with qualitative approach. The resources data in this research are primary data and secondary data. The primary data is data collected by students themselves by interview directly. The secondary data is data gained by the archive, documents related to the research. The sampling technique in this research is a nonprobability sampling. It means that the object of this research is chosen not randomly because not all students have the same chance to choose. Data collection techniques used in this research are by observing, interview, and documentation. Observing in this research means notice and observing systematically related to the research. I this case researcher doing observing the class and notice all things of the teachinglearning process. Interviews mean data collection by doing an interview with students and the lecture itself. So, the researcher did an interview with the student about materials and also 
their difficulties when learning English. By interview, the researcher knows what their problem during learning. Documentation means data gained by books, magazines, or archive. In this case, the researcher uses a teaching journal, absent, and also notes from the lecturer. This researcher used the Triangulasi method and Triangulasi resources in checking and validity of the data, this case done by comparing the result of observing, interviewing, and documenting analysis.

\section{Implication}

The total number of students in the pharmacy is 28 persons. In the teaching-learning process, the lecture has an important role to make the process run well and succeed in transfer knowledge. To support the success of the teaching-learning process, the lecturer should have good media in learning and one of them is by giving comics. The comic has a lot of advantages in learning English especially learning vocabulary. The comic contains any pictures, colorful, simple sentences, and words so that students essay to memorize the materials when they learn by the comic. By comic wishes students interesting, enjoy and happy to learn English vocabulary.

Based on observation and interview results of students, it gained that before lecture use comic as learning media, students bored, unenthusiastic, and monotonous to learn English so that they don't understand the materials, stress when they have class and also uncomfortable to follow the lesson. They willing the class end soon, and with the lecture didn't come to the class to teach. Most students did not pay attention to the lesson and do other tasks in the classroom because they are not interested in the lesson. The observation result also showed that students only sit quietly during the process of learning. They suppose to listen carefully but actually, they did not understand the materials. Some students read other books while sitting nicely and some of them played with their handphones.

After implementing a comic for the students the atmosphere of the class was changed. The first of implementing comics in the classroom, most students feel confused and quarrel about the comic. The lecture gives them 10 minutes to control class. And after that lecture explains the use of comics and how they should learn y comic. Every student has a slice of paper-related material in comic form. The student should list words related materials in the column and choose sentences on the other side and after that, they should fulfill the balloons of comic. This activity is so interesting and involves all the students in the classroom. There were not students sit only and played handphones more. All of them give a contribution of the teaching-learning in the classroom. The lecture gives chance to students to share their ideas, opinion, and point of view about the materials after finish the lesson. The class is so happy, nicely and also lively. 
The comic also helps students interact and communicate with other students and lecturers in discuss materials. They talk more about materials because one student and other groups have a different picture to compare. Sometimes lecture divided class into a small group or presenting classroom. Every student has different imagination about pictures given so that it increases students' curiosity in learning. The comic is useful to help students to understand materials and catch the point of materials. Besides, there was an improvement present list in every meeting. There was no absence when the English class began. The class is so full and always ends happily. No one student comes too late to the class when they knew English class with a comic was started. The willingness of students to learn improves so higher. It showed that the comic helps students in every learning English and motivate them to more active in asking materials.

\section{Conclusion}

According to the result of the research, it can be concluded that comic is one of the media to help students in learning vocabulary. Comic increases students' creativity and curiosity in learning, besides, students feel happy, enthusiastic, enjoy, and comfort to learn in every meeting. Implementing comics in the teaching-learning process also helps students to improve their marks in English subject. The more essay to understand material and talk actively to show their ideas and opinion related materials. So it can be said that implementing comics is beneficial to help students in learning vocabulary for students in pharmacy class in STIKes Buleleng.

\section{Reference}

Hatch,E.M and C.Brown. 1995. 'Vocabulary Sentence and Languange Education' Cambridge: Cambridge Press university.

https://jurnal.lp2msasbabel.ac.id/inde x.php/stu/article/download/483/ 21/

http://jurnal.untan.ac.id/index.php/jp dpb/article/dowload/23241/1836 1/

www.genayang.com/comicsedu/stren ght,html 